\title{
Scleral patch as a definitive treatment for hypotonic maculopathy after trabeculectomy
}

\author{
Enxerto de retalho escleral de doador como tratamento \\ definitivo de maculopatia hipotônica pós trabeculectomia
}

Neilzo Nunes Oliveira'; Leonardo Bittencourt Silveira'; Isadora Oliveira Jeha'; João Antonio Prata Junior ${ }^{1}$

\begin{abstract}
A female patient with juvenile glaucoma without clinical control underwent a trabeculectomy with mitomycin C, and developed eye hypotension which did not respond to conservative treatment, with subsequent hypotonic maculopathy. The patient was treated using a scleral patch provided by a donor above the fistula, which improved intraocular pressure and visual acuity. The use of the scleral patch above the fistula seems an adequate therapy to treat ocular hypotension due to the over-filtering trabeculectomy bubble. The surgeon should consider this technique when planning surgical solutions for such cases. etiology

Keywords: Glaucoma; Trabeculectomy/adverse effects; Sclera/transplantation; Mitomycin/therapeutic use; Ocular hypotension/
\end{abstract}

\section{ReSUMO}

Paciente do sexo feminino, portadora de glaucoma juvenil sem controle clínico adequado, foi submetida à trabeculectomia com mitomicina $\mathrm{C}$, após a qual, desenvolveu hipotensão ocular refratária às medidas conservadoras, evoluindo com um quadro de maculopatia hipotônica. Foi realizado um implante de enxerto de retalho escleral de doador sobre a fístula, com resolução do quadro e ganho de acuidade visual. A enxertia de retalho escleral de doador mostrou-se uma terapia adequada para correção da hipotensão ocular por bolha hiperfiltrante pós trabeculectomia. O cirurgião deve considerar o emprego dessa técnica ao programar a revisão destes casos.

Descritores: Glaucoma; Trabeculectomia/efeitos adversos; Esclera/transplante; Mitomicina/uso terapêutico; Hipotensão ocular/etiologia

\footnotetext{
${ }^{1}$ Universidade Federal do Triângulo Mineiro, Uberaba, MG, Brazil. 


\section{INTRODUCTION}

$\mathbf{0}$ ne of the postoperative complications of trabeculectomy is the occurrence of eye hypotonia (intraocular pressure less than $6 \mathrm{mmHg}$ ), which can be caused by: increasing the flow of aqueous humor (AH) as in cases of hyperfunctioning bubble; conjunctival leakage of $\mathrm{AH}$ (positive Seidel); reducing the production of $\mathrm{AH}$ resulting from ciliocoroidal detachment or some inflammatory process ${ }^{(1-2)}$.

Extended hypotension can result in the development of hypotonic maculopathy, characterized by low visual acuity (LVA), and characteristic signs in the eye fundus examination, as retinal streaks, coroidal effusion, and papilla edema. ${ }^{(1-3)}$. The use of antiproliferative medication in the filtering surgeries such as 5fluorouracil and mitomycin $\mathrm{C}$ greatly increased the incidence of these complications ${ }^{(2)}$. There are studies reporting $20 \%$ of hypotonia incidence in eyes with intraoperative exposure to mitomycin C (0.54 mg per $\mathrm{ml})$ for 3.5 minutes, and $35.7 \%$ in longer periods. ${ }^{(2)}$

In the literature, there are reports proposing different solutions to cases of maculopathy associated to bubble hyperfunction. La Borwit et al. reported the results of the reduction and repair of the blister. ${ }^{(4)}$ Cronemberger et al. described the resection of the hyperfunctioning bubble. ${ }^{(5)}$ Leen et al., and Wise et al., in turn, have analyzed the autologous blood injection for correcting hyperfiltration. ${ }^{(6-7)}$ Grady et al. described the use of tissue adhesive. ${ }^{(8)}$ Gomes et al. studied the use of amniotic membrane for such purpose ${ }^{(9)}$. Ventura et al. described the use of compression suture ${ }^{(10)}$.

In the national literature there are few reports to the maculopathy approach. Therefore, this study aims at describing a case of post-trabeculectomy hypotonic maculopathy with use of mitomycin $\mathrm{C}$, in addition to the developments of the case, and the procedure to implant a scleral patch from a donor to correct the problem and stabilize the intraocular pressure (IOP) and visual acuity (VA).

\section{Case Report}

Patient ELM, 44 years old, female, melanodermic, from Maranhão, smoker, with a family history of juvenile glaucoma, four blind brothers, sent in 2010 for evaluation of low visual acuity (LVA), worse in the right eye (RE) for one year, and with strabismus in this eye for six months.

In July 2010 the clinical examination of the patient was held at the glaucoma ambulatory of Universidade Federal do Triangulo Mineiro (UFTM), which showed: corrected visual acuity (CVA): figures in the RE and 20-20 in the left eye (LE). The tonometry was $24 \mathrm{mmHg}$ in the $\mathrm{RE}$ and $17 \mathrm{mmHg}$ in the LE. Gonioscopy showed open angle 360 degrees in both eyes (BE). The visual field showed a small island of temporal vision in the right eye, and arcuate scotoma in the left eye. Fundoscopy shows the optic nerve with excavation of 0.9 and 0.7. Advanced juvenile glaucoma was diagnosed, and the treatment started with travoprost $0.04 \%$, brimonidine $0.1 \%$ and brinzolamide $1 \%$, with a goal of intraocular pressure (IOP) of less than $15 \mathrm{mmHg}$.

After nine months without follow up on the service, the patient returned to the ambulatory with incorrect use of medications. At the exam, CVA: light perception (LP) and 20/80, Tonometry: $44 \mathrm{mmHg}$ in the RE and $32 \mathrm{mmHg}$ in the LE; optical disk with excavation: 1.0 in the RE and 0.7 in the LE. Timolol $0.5 \%$ every 12 hours and brimonidine $0.1 \%$ every 12 were then reintroduced, and oral acetazolamide $(250 \mathrm{mg})$ every 8 hours was added. Due to the irregularity of the clinical treatment associated to worsening of the condition, trabeculectomy (TREC) was recommended, and thus the preoperative exams were requested for both eyes.

The patient was submitted to TREC with intraoperative application of mitomycin $\mathrm{C}(0,5 \mathrm{mg} / \mathrm{ml}$ for two minutes $)$ in the LE, with no complications. After 30 days, the same procedure was performed in the RE. The patient had ambulatory followup, with intraocular pressure always below $15 \mathrm{mmHg}$, and with no use of hypotensive medications, bilaterally.

Approximately nine months after TREC of the LE, the patient complained of LVA even with the use of correction. To the exam: CVA: LP and 20:100; tonometry: 02 and $02 \mathrm{mmHg}$. Biomicroscopy showed a formed and thin bubble in BE. Eye fundus: total excavation and 0.8 and choroidal folds in the LE. Optical coherence tomography (OCT) performed (Cirrus HD OCT model 4000 provided by Zeiss Meditec Corporation, Jena, Germany) (Figure 1).
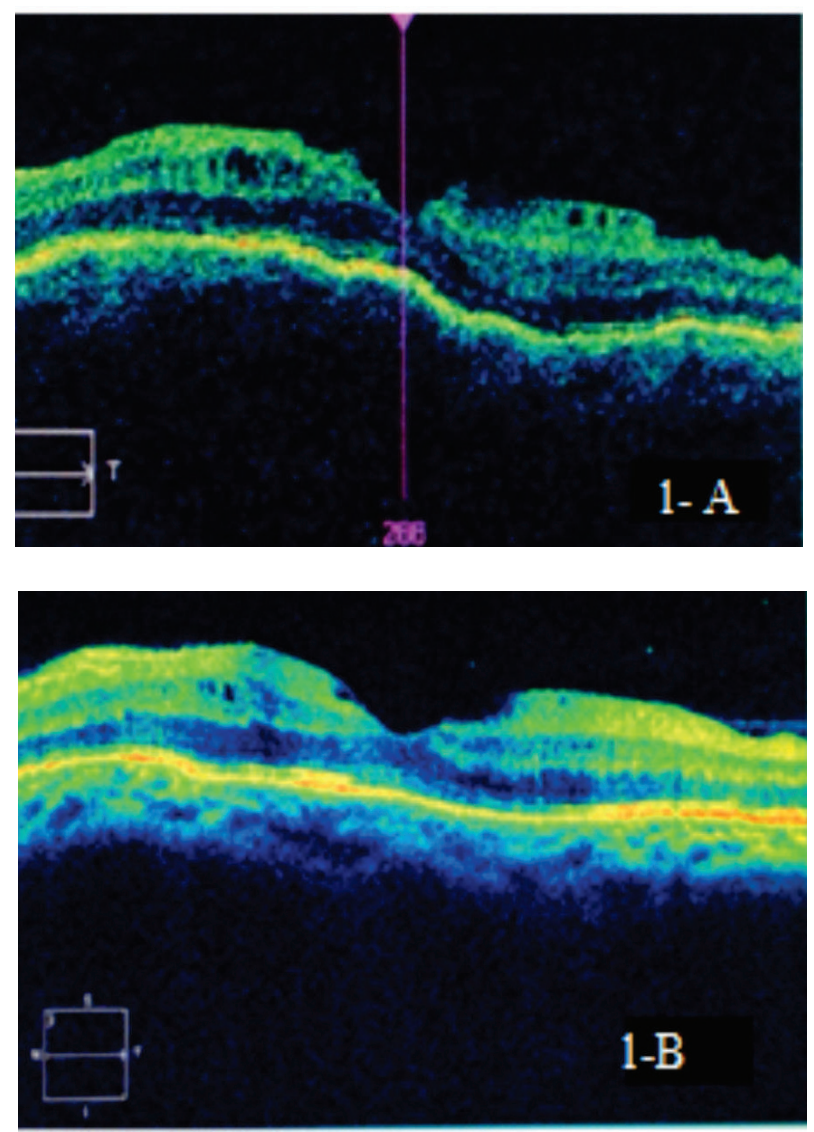

Figure 1: a) OCT showing accumulation of subretinal fluid, choroid folding compatible with hypotonic maculopathy. b) important resolution of the condition after treatment.

A bubble review was indicated for injection of fibrin glue. The procedure had satisfactory results, and provided the control of hyperfiltration and the maculopathy resolution. Visual acuity after 30 days was LP and 20:60; tonometry: $10 \mathrm{mmHg}$ and 6 $\mathrm{mmHg}$ and elevated bubble in BE with negative Seidel test and eye fundus without signs of maculopathy. 
Initially, the IOP was stabilised in $10 \mathrm{mmHg}$ in both eyes without medication, but the patient once again lost the contact with the service, and one year afterwards reappeared complaining of LVA in the LE. At the exam, CVA: NLP and 20:200; Tonometry: $10 \mathrm{mmHg}$ in the RE and $03 \mathrm{mmHg}$ in the LE. Biomicroscopy: elevated bubble in both eyes. Fundoscopy showed again chorioretinal folds in the papilomacular beam and in the macula, which confirmed the diagnosis of hypotonic maculopathy.

A review of trabeculectomy was scheduled to control hyperfiltration. During the procedure, after the opening of the conjunctiva, the anterior chamber was broken and it was not possible to identify the scleral patch for additional suture to restrict the hyperfiltration. After irrigation of the anterior chamber with a balanced saline solution for a time paracentesis it was possible to identify the location of the fistula, and on it a scleral patch measuring $04 \times 05 \mathrm{~mm}$ from a donor was sutured with stitches of mononylon 10.0. The BSS infusion by the paracentesis allowed to redo the anterior chamber and adjusting the number of sutures needed for their maintenance, which was achieved with three stitches.

A week later, the patient reported improved vision. CVA showed: NPL and 20-70 ( -1.50c x 180), Tonometry in the LE (15h): $09 \mathrm{mmHg}$, Biomicroscopy: chamber formed, elevated bubble and scleral patch well positioned (Figure 2-A).

The patient had a favorable development, being possible to discontinue hypotensive medication and glucocorticoids, continuing with CVA: $20: 40$ (-1.75 x 180) in the LE, tonometry: $10 \mathrm{mmHg}$ and $09 \mathrm{mmHg}$, bubble formed in both eyes (Figure $2 \mathrm{~b}$ ) and eye fundus with no hypotonic maculopathy after five months postoperatively.
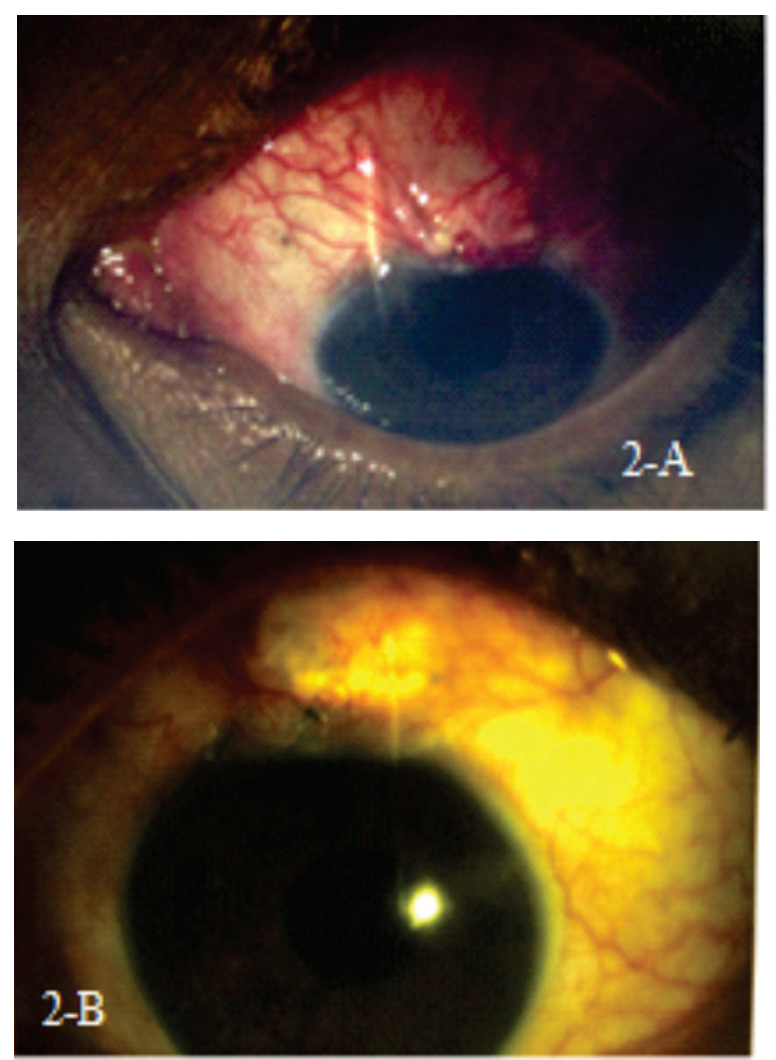

Figure 2: a) immediate postoperative period showing a formed chamber and an elevated bubble. b) appearance six weeks afterwards showing an elevated bubble and proper placement of the scleral patch.

\section{Discussion}

There is still no ideal therapy for the hyperfiltration condition post trabeculectomy. Several techniques have been used, such as the pressure dressing, bandage contact lens, bubble resection $^{(5)}$, autologous blood injection ${ }^{(6-7)}$, tissue adhesive ${ }^{(8)}$, graft of amniotic membrane ${ }^{(9)}$ and compression suture ${ }^{(10)}$. In this case, the first option chosen was the injection of fibrin glue inside the bubble, that despite the favorable initial results over time proved ineffective. Certainly, the initial result was due to the action of glue, lost after the delayed absorption of it.

Cronemberger et al. ${ }^{(5)}$ conducted a work in Brazil where they made the resection of the bubble to review the scleral bed, being effective in the treatment of hypotonia, and low postprocedure morbidity. But in this case it was not possible due to the large extent of the filtering bubble and impossible identification of the scleral patch.

The next compression suture the scleral flap to bubble remodeling, is another effective method of treating hyperfiltrating bubble ${ }^{(10)}$. However, it is not without complications. Wang et al. ${ }^{(11)}$ describe a case of extensive formation of corneal stromal infiltrates, with opacification after using this technique on a 24year-old man. This result can be explained by the constant tension applied to the structures adjacent to the suture, such as the cornea. Again due to great extent of the filtering bubble it was not possible to follow this technique.

Lettre et al. ${ }^{(12)}$ promoted the transconjunctival resuture of the scleral patch in eyes with post-trabeculectomy hypotony in a series of 35 cases and obtained $94 \%$ success. Eha et al. ${ }^{(13)}$, in similar technique, observed improvement in the visual acuity of $20 / 160$ to $20 / 63$ in a period of six months. Eha et al. ${ }^{(14)}$, in 2013, after a 4-year follow-up of the same technique showed an improvement in the average visual acuity of 0.8 logarithm of the minimum angle of resolution (logMAR); the macular folds were resolved in all patients and the resolution of the choroidal detachment in $96 \%$ of cases. In the case reported above, this strategy was not used because the identification of the scleral patch was not possible intraoperatively.

The case discussed here obtained resolution of ocular hypotonia and maculopathy by revising the TREC with use of the scleral patch from the donor.

So it's very important that the surgeon consider preoperatively the need for the use of a scleral patch, in order to correct the consequent hypotonia of hyperfiltration of the trabeculectomy bubble.

\section{ReFERENCES}

1. Weyll M, Gilio A, Barbosa A, Nicoli AA, Silveira RC. Detecção de maculopatia hipotônica subclínica pelo OCT III após cirurgia filtrante. Arq Bras Oftalmol. 2006; 69(6): 823-5.

2. Guedes VR, Simmons RB, Pakter HM, Simmons RJ. Persistent hypotony after primary trabeculectomy with mitomycin C. Arq Bras Oftalmol. 2000; 63(3): 179-83.

3. Karasheva G, Goebel W, Klink T, Haigis W, Grehn F. Changes in macular thickness and depth of anterior chamber in patients after filtration surgery. Graefes Arch Clin Exp Ophthalmol. 2003; 241(3):170-5.

4. La Borwit SE, Quigley HA, Jampel HD. Bleb reduction and bleb repair after trabeculectomy. Ophthalmology. 2000;107(4):712-8. 
5. Cronemberger S, Santos DV, Oliveira AC, Maestrini HA, Calixto N. Ressecção de bolsa hiperfuncionante para tratamento de hipotonia ocular crônica: relato de casos. Arq BrasOftalmol. 2004; 67(4): 637-44.

6. Leen MM, Moster MR, Katz LJ, Terebuh AK, Courtland M, Schmidt CM, Spaeth GL. Management of overfiltering and leaking blebs with autologous blood injection. Arch Ophthalmol. 1995; 113(8):1050-5.

7. James B, Wise MD. Treatment of chronic postfiltrationhypotony byintrableb injection of autologous blood. Arch Ophthalmol. 1993; 111(6): 827-30.

8. Grady FJ, Forbes M. Tissue adhesive for repair of conjunctival buttonhole in glaucoma surgery. Am J Ophthalmol. 1969; 68(4): 656-8.

9. Gomes JA, Fernandes LH, Komagome CM, Höfling-Lima AL, Prata Jr. JA. Uso de membrana amniótica no tratamento de complicações pós-trabeculectomia. Arq Bras Oftalmol. 2001; 64(5): 437-41.
10. Ventura AGGM, Cavalcanti HDO, Holanda AGS, Cardoso G, Trigueiro L. Tratamento de bolhas hiperfiltrantes por sutura de compressão. Rev Bras Oftalmol. 2002;61(7):525-8.

11. Wang GW, Gonzalez E, Lin SC. Extensive intracorneal deposition after compression sutures for the treatment of hypotony maculopathy. J Glaucoma. 2011;20(4):244-5.

12. Letartre L, Basheikh A, Anctil JL, Des Marchais B, Goyette A, Kasner OP,Lajoie C. Transconjunctival suturing of the scleral flap for overfiltration with hypotony maculopathy after trabeculectomy. Can J Ophthalmol. 2009;44(5):567-70.

13. Eha J, Hoffmann EM, Wahl J, Pfeiffer N. Flap suture-a simple technique for the revision of hypotony maculopathy following trabeculectomy with mitomycin C.Graefes Arch Clin Exp Ophthalmol. 2008;246(6):869-74.

14. Eha J, Hoffmann EM, Pfeiffer N. Long-term results after transconjunctivalresuturing of the scleral flap in hypotony following trabeculectomy. Am J Ophthalmol. 2013;155(5):864-9. 